\title{
Pengaruh edukasi stimulasi terhadap
perkembangan kognitif anak usia dini $\quad$ OJS
}

\author{
Marilin Kristina ${ }^{1, a)}$, Ruly Nadian Sari ${ }^{2, b)}$ \\ ${ }^{1)}$ STMIK Pringsewu, ${ }^{2)}$ STIT Pringsewu \\ Corresponding Author: marilinkristina0104@gmail.com,rulynadiansari@gmail.com
}

\begin{abstract}
In pre-school age, children generally show significant development, especially in aspects of cognitive development.This happens because in pre-school age is a golden age that is often called golden age.Cognitive development is not necessarily able to take place optimally without the stimulus or stimulation given to pre-school age children.Lack of stimulation given to pre-school age children can result in loss of brain cells function so that it will impact the slow cognitive development and impact on the child's ability to process the information received.The research method in this study is to use literature studies based on the results of analysis of the results of research used as literature in this study.The procedure in conducting literature studies in this study is to determine the formulation of problems, find relevant literature, evaluate the data obtained, analyze and then interpret the data that has been obtained.Based on the study of literature can be obtained the conclusion that the provision of stimulation education in pre-school age children can improve the cognitive development of pre-school age children.
\end{abstract}

Keyword: education,stimulation, cognitive development

\begin{abstract}
Abstrak
Pada usia pra sekolah, pada umumnya anak-anak memperlihatkan perkembangannya yang cukup signifikan terutama pada aspek perkembangan kognitifnya. Hal ini terjadi karena di usia pra sekolah merupakan usia emas yang sering disebut golden age. Perkembangan kognitif tersebut tidaklah serta merta dapat berlangsung secara optimal tanpa adanya stimulus atau rangsangan yang diberikan kepada anak usia pra sekolah. Kurangnya stimulasi yang diberikan pada anak usia pra sekolah.dapat mengakibatkan hilangnya fungsi sel-sel otak sehingga akan berdampak lambatnya perkembangan kognitifnya dan berdampak pada kemampuan anak dalam mengolah informasi yang diterima.

Metode penelitian pada penelitian ini yaitu menggunakan kajian literature yang berdasarkan dari hasil analisis hasil penelitian yang digunakan sebagai literature dalam penelitian ini. Adapun prosedur dalam melakukan kajian literature dalam penelitian ini adalah menentukan formulasi permasalahan,mencari literature yang relevan, mengevaluasi data yang diperoleh, menganalisis dan kemudian menginterpretasikan data yang telah diperoleh. Berdasarkan kajian literatur dapat diperoleh kesimpulan bahwa pemberian edukasi stimulasi pada anak usia pra sekolah dapat meningkatkan perkembangan kognitif anak usia pra sekolah.
\end{abstract}

Kata Kunci: edukasi, stimulasi, perkembangan kognitif

Histori Artikel:

1. Tanggal submit 16 Juni 2021

2. Tanggal review 16 Juni 2021

3. Tanggal diterima 28 Juni 2021 


\section{Pendahuluan}

Pemberian stimulasi pada anak usia dini merupakan hal yang sangat penting dikarenakan anak dalam masa pertumbuhan dan perkembangan anak. Teori perkembangan kognitif Piaget menyatakan bahwa bahwa anakanak secara aktif membangun pemahaman mengenai dunia melalui empat tahap perkembangan kognitif yaitu tahap sensorimotor, tahap praoperasi, tahap operasi kongkret dan tahap operasi formal. (Santrock, 2011) Teori kognitif berkontribusi dalam menyajikan suatu pandangan yang positif mengenai perkembangan dan mengedepankan usaha aktif individu dalam menyusun pemahamannya.

Dalam Mursintowati dijelaskan stimulasi merupakan perangsangan dan latihan terhadap kepandaian anak yang sifatnya datang diluar individu anak itu sendiri. Stimulasi ini dapat dilakukan oleh orang tua anak, anggota keluarga atau pun dapat juga berasal dari orang-orang yang lebih dewasa di sekitar anak. (Mursintowati, 2002)

Stimulasi merupakan bagian dari kebutuhan dasar anak yaitu asah. Dengan mengasah kemampuan anak secara terus menerus, akan semakin meningkatkan kemampuan anak. Untuk memberikan stimulasi, dapat dilakukan dengan latihan dan bermain. Anak yang mendapatkan stimulasi yang terarah akan cepat berkembang dibanding anak yang kurang mendapat stimulasi. Aktivitas bermain tidak selalu menggunakan alatalat permainan, meskipun alat permainan penting untuk merangsang perkembangan anak.

Pemberian stimulasi diharapkan memberikan dampak yang positif terhadap perkembangan anak dalam memasuki usia sekolah. Anak yang pada usia pra sekolah yang telah mendapatkan stimulasi secara berkelanjutan cenderung siap memasuki dunia sekola

Usia balita memiliki peran yang sangat penting dalam masa pertumbuhan manusia, hal ini tentu saja memerlukan peran serta orangtua dalam proses pembinaanya dikarenakan balita menghabiskan waktunya dekat dengan orangtuanya. Sebagai pengasuh dan pendidik pertama dan utama, orangtua diharapkan mampu mempengaruhi tumbuh kembang anak secara optimal melalui stimulasi tumbuh kembang, pemenuhan kebutuhan gizi, perawatan dasar termasuk imunisasi, pengobatan bila sakit, tempat tinggal yang layak, sanitasi lingkungan, sandang, kesegaran jasmani. (Soetjiningsih \& Wahab,A, 2014)

Pemberian stimulasi sejak dini pada anak usia pra sekolah yang diberikan oleh orangtua dapat memberikan efek yang positif yaitu dapat meningkatkannya perkembangan bahasa dan memori anak, meningkatkan kesiapan anak dalam sekolah serta dapat membantu anak untuk mengoptimalkan potensi yang dimiliki. Dalam John W .Santrock pengasuhan dan pengalaman lingkungan memiliki peranan terhadap perkembangan anak usia dini.(Santrock, 2011)

Sejauh mana isu pengasuhan orangtua dalam hal ini sejauh mana pemberian edukasi stimulasi dapat mempengaruhi tumbuh kembang anak usia pra sekolah secara perkembangan kognitif, Berangkat dari isu ini maka penulis tertarik untuk mengkajinya lebih dalam.

\section{Metode Penelitian}

Desain penelitian ini adalah literature review atau tinjauan pustaka. Penelitian kepustakaan atau literature merupakan penelitian yang mengkaji atau meninjau secara kritis pengetahuan, gagasan, atau temuan yang terdapat dalam tubuh literature yang berorientasikan akademik serta merumuskan kontribusi yang dapat diperoleh secara teoritis dan metodelogisnya untuk topik atau bidang tertentu. Uraian tentang literatur yang relevan dengan bidang tertentu yang ditemukan dalam buku ilmiah. (Cooper, 2010). Sifat dalam penelitian ini adalah menggunakan penelitian analisis deskriptif yaitu penguraian data yang telah diperoleh secara teratur kemudian diberikan pemahaman dan penjelasan agar dapat dipahami dengan baik oleh pembaca.

\section{Hasil Penelitian}

Berdasarkan penelusuran tersebut dapat diperoleh dari beberapa literature yang memenuhi kriteria yang ditetapkan. Secara rinci hasil penelusuran dapat dilihat pada tabel 1 


\begin{tabular}{|c|c|c|c|c|}
\hline No. & Peneliti & Subjek Penelitian & Variabel Terkait & Hasil \\
\hline 1. & $\begin{array}{l}\text { Siska } \\
\text { Abidah, } \\
\text { Novianti }\end{array}$ & $\begin{array}{l}80 \text { orang ibu yang } \\
\text { memiliki anak usia } 0- \\
5 \text { tahun di } \\
\text { Wonokromo } \\
\text { Surabaya }\end{array}$ & $\begin{array}{l}\text { Pengaruh Edukasi } \\
\text { Stimulasi Tumbuh } \\
\text { Kembang Terhadap } \\
\text { Kemampuan } \\
\text { Deteksi } \\
\text { Tumbuh Kembang } \\
\text { Anak }\end{array}$ & $\begin{array}{l}\text { Pengetahuan orang tua } \\
\text { menjadi salah satu } \\
\text { factor penunjang dalam } \\
\text { mendukung stimulasi } \\
\text { perkembangan anak }\end{array}$ \\
\hline 2. & $\begin{array}{lr}\text { Febriana } & \text { Suci } \\
\text { Hati, } & \text { Prasetya } \\
\text { Lestari } & \end{array}$ & $\begin{array}{l}90 \text { balita kelompok } \\
\text { kasus dan } 90 \text { balita } \\
\text { kelompok control di } \\
\text { Sedayu, } \quad \text { Bantul } \\
\text { Yogyakarta }\end{array}$ & $\begin{array}{l}\text { Pemberian } \\
\text { Stimulasi pada } \\
\text { perkembangan anak } \\
\text { usia } 12-36 \text { bulan }\end{array}$ & $\begin{array}{lr}\text { Terdapa hubungan } \\
\text { positif kuat dan } \\
\text { signifikan antara } \\
\text { stimulasi tumbuh } \\
\text { kembang anak }\end{array}$ \\
\hline 3 & $\begin{array}{l}\text { Bestarindra } \\
\text { Ramadhania, dkk }\end{array}$ & $\begin{array}{l}\text { Anak usia dini usia } \\
\text { TK }\end{array}$ & $\begin{array}{l}\text { Pengaruh Stimulasi } \\
\text { Pembelajaran } \\
\text { Terhadap } \\
\text { Perkembangan } \\
\text { Kognitif Anak Usia } \\
\text { Dini }\end{array}$ & $\begin{array}{l}\text { Pemberian stimulus } \\
\text { terhadap anak usia dini } \\
\text { dapat mempengaruhi } \\
\text { perkembangan kognitif } \\
\text { anak usia dini }\end{array}$ \\
\hline 4 & Nidatul Khofiyah & $\begin{array}{lr}20 & \text { responden } \\
\text { kelompok } & \text { intervensi } \\
\text { dan 20 } & \text { reponden } \\
\text { kelompok } & \text { control di } \\
\text { posyandu } & \text { Desa } \\
\text { Tanbakrejo } & \end{array}$ & $\begin{array}{l}\text { Edukasi } \\
\text { Berpengaruh } \\
\text { terhadap pemberian } \\
\text { stimulasi } \\
\text { perkembangan anak } \\
\text { usia } 12-24 \text { bulan } \\
\text { oleh ibu }\end{array}$ & $\begin{array}{lr}\text { Pemberian stimulasi } \\
\text { perkembangan anak } \\
\text { yang baik dan terarah } \\
\text { secara teratur } \\
\text { meningkatkan } \\
\text { perkembangan anak. }\end{array}$ \\
\hline 5 & Elmanora, dkk & $\begin{array}{l}120 \text { anak usia } \\
\text { prasekolah dan ibu di } \\
\text { Kota Jambi }\end{array}$ & $\begin{array}{l}\text { Lingkungan } \\
\text { Keluarga sebagai } \\
\text { Sumber Stimulasi } \\
\text { Utama untuk } \\
\text { Perkembangan } \\
\text { Kognitif Anak Usia } \\
\text { Prasekolah }\end{array}$ & $\begin{array}{l}\text { Pendidikan pra sekolah } \\
\text { yang berkualitas } \\
\text { memiliki } \\
\text { perkembangan kognitif } \\
\text { yang berkualitas. }\end{array}$ \\
\hline
\end{tabular}




\section{Pembahasan}

Berikut faktor-faktor yang dapat mempengaruhi perkembangan kognitif anak usia dini:

1. Pemberian Edukasi Stimulasi Tumbuh Kembang Anak Sejak Dini

Pemberian edukasi stimulasi tumbuh kembang anak sejak dini oleh orang tua dapat meningkatkan kemampuan orangtua dalam memberikan stimulasi tumbuh kembang anak sejak dini yang kemudian akan berdampak positif seperti dapat meningkatkan perkembangan bahasa dan memori anak. Edukasi stimulasi ini dapat diperoleh orangtua ataupun pengasuh dengan cara mengikuti penyuluhan-penyuluhan yang berkaitan informasi tumbuh kembang anak ataupun orangtua dapat membaca dan menggali referensi bacaan yang berkaitan dengan tumbuh kembang anak usia dini.

2. Interaksi antara lingkungan dan stimulasi dapat membantu perkembangan otak dalam menyusun struktur syaraf.

Stimulasi memiliki peran penting dalam meningkatkan pertumbuhan dan perkembangan anak terutama fungsi kognitif, afektif dan psikomotor. Stimulasi dari orangtua serta status gizi merupakan dua faktor yang berpengaruh pada pertumbuhan dan perkembangan anak usia 1-3 tahun. Dalam pemberian stimulasi hendaknya memperhatikan kebutuhan anak sesuai fase perkembangannya terutama apabila dilakukan pada periode penting golden periode yaitu saat usia kehamilan Trimester III hingga dua tahun pertama kehidupan anak atau yang sering disebut 1000 hari pertama kehidupan.

3. Pemberian rangsangan berupa pendidikan, pola asuh, metode bermain,dan pola dalam belajar dapat meningkatkan perkembangan kognitif anak usia dini.

Kualitas dan kompleksitas sistem rangkaian antar sel-sel otak pada anak sangat ditentukan oleh rangsangan yang diberikan oleh lingkungan terdekat anak. Orangtua harus terus menerus melakukan stimulasi agar kemampuan otak anak dapat selalu berkembang mengikuti rangsangan yang diberikan oleh orang tua dan lingkungannya. Juka pada usia golden age anak tidak mendapatkan stimulasi yang baik maka pusatpusat otak yang aktif menjadi terbatas sehingga dapat mempengaruhi perkembangan kognitif anak.

4. Pendidikan dan pengetahuan ibu

berpengaruh pada perkembangan kognitif anak usia dini
Ibu dengan pendidikan rendah cenderung tidak dapat memberikan stimulasi perkembanagn yang optimal sehingga anak tidak mampu mencapai perkembangan yang optimal pula.(Khofiyah, 2020). Hal ini sangat relevan denga istilah ibu adalah sekolah pertama untuk anak-anaknya. Dimana seorang ibu memiliki peran penting dalam mendidik dan menstimulasi pertumbuhan dan perkembangan anak tertutama perkembangan kognitif dan motorik anak.

Perkembangan kognitif anak dapat berkembang jika anak diberikan stimulasi yang tepat yang dapat mendukung perkembangan kogtif dan bahasa anak usia dini. Tentu saja dalam memberikan stimulus tersebut memerlukan keterampilan yang dilandasi pengetahuan mulai dari pola asuh anak, pola asuh gizi dan lingkungan yang mendukung.

5. Perkembangan kognitif anak ditentukan oleh stimulasi dari lingkungan keluarga dan lingkungan sekolah.

Dalam Elmanora dikatakan teori ekologi Bronfenbrenner bahwa keluarga dan sekolah merupakan bagian dari lingkungan yang dapat memberikan pengaruh dalam menentukan perkembangan kognitif anak.(Elmanora et al., 2017) Namun dijelaskan lebih rinci lagi lingkungan keluarga lebih memiliki kontribusi yang lebih besar daripada lingkungan sekolah dalam mempengaruhi perkembangan kognitif anak. Pendidikan ibu dan pendapatan keluarga juga memiliki pengaruh yang tak kuat dalam menentukan kualitas lingkungan fisik dan pengalamanbelajar pada anak.(Klebanov et al., 1994)

\section{Kesimpulan}

Berdasarkan kajian literature diperoleh kesimpulan bahwa pemberian stimulasi terhadap anak usia pra sekolah dapat mempengaruhi perkembangan kognitif anak usia pra sekolah. Pemberian stimulasi ini dapat dalam bentuk memberikan edukasi stimulasi perkembangan anak yang diberikan kepada ibu atau pengasuh secara rutin dan terarah agar dapat diterapkan pola pengasuhan dan pemberian stimulasi yang tepat kepada anak pra sekolah dalam menstimulus perkembangan kognitifnya. Selain itu tinggat pendidikan ibu juga sangat berpengaruh pada pola asuhnya terhadap anak, ibu yang memiliki pendidikan tinggi memiliki perekonomian yang baik sehingga berdampak pada pola gizi dan pemilihan pra sekolah formal anak yang 
kemudian ikut memiliki peran dalam

perkembangan kognitif anak usia pra sekolah.

\section{Daftar Pustaka}

Bestarindra Ramadhania P,dkk, (2021)

Pengaruh Stimulasi Pembelajaran

Terhadap Perkembangan Kognitif Anak

Usia Dini, Prosiding Seminar Nasional dan

Call Paper Mahasiswa, Fakultas

Pendidikan Psikologi Universitas Negeri

Malang

Elmanora, E., Hastuti, D., \& Muflikhati, I. (2017). Lingkungan Keluarga sebagai Sumber Stimulasi Utama untuk Perkembangan Kognitif Anak Usia Prasekolah. Jurnal Ilmu Keluarga dan Konsumen, 10(2), 143-156. https://doi.org/10.24156/jikk.2017.10.2.14 3

Khofiyah, N. (2020). Edukasi Berpengaruh terhadap Pemberian Stimulasi Perkembangan Anak Usia 12-24 Bulan oleh Ibu di Posyandu Desa Tambakrejo Kabupaten Puworejo. Jurnal Ners Dan Kebidanan (Journal of Ners and Midwifery), 7, 231-238. https://doi.org/10.26699/jnk.v7i2.ART.p23 $1-238$

Klebanov, P. K., Brooks-Gun, J., \& Duncan, G. J. (1994). Does Neighborhood and Family Poverty Affect Mother's Parenting, Mental Health and Social Support. Journal of Marriage and the Family, 56 (2), 441-445. https://doi.org/10.2307/353111

Mursintowati. (2002). Tumbuh Kembang Anak dan Remaja. Sagung Seto.

Santrock, J. W. (2011). Life-Span Development, Perkembangan Masa Hidup: Vol. Jilid I. Hill Companies.

Siska Nurul Abidah, Hinda Novianti, (2020) Pengaruh Edukasi Stimulasi Tumbuh Kembang terhadap Kemampuan Deteksi Dini Tunbuh Kembang Anak Usia 0-5 Tahun Oleh Orangtua, Jurnal Ilmu Kesehatan, Vol.14 No.2, 89-93, http://jurnal.poltekkespalu.ac.id/index.php/ JIK

Suci Hati, Febriana, Lestari Prasetya, Pengaruh Pemberian Stimulasi pada Perkembangan Anak Usia 12-36 Bulan di Kecamatan Sedayu, Bantul, Jurnal Ners dan Kebidanan Indonesia, Vol. 4 No.1, 44-48, https://ejournal.almaata.ac.id/index.php/JN KI 